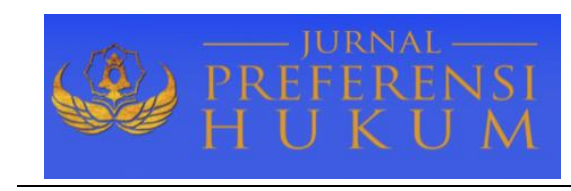

Jurnal Preferensi Hukum | ISSN: XXXX | E-ISSN: XXXX

Vol. 1, No. 2 - September 2020, Hal. 78-82| Available Online at https://www.ejournal.warmadewa.ac.id/index.php/juprehum

DOI: http://doi.org/10.22225/jph.v1i2.2379.78-82

\title{
KEDUDUKAN AHLI WARIS YANG BERPINDAH AGAMA DALAM HARTA WARIS MENURUT HUKUM WARIS ADAT BALI
}

\author{
Dewa Ayu Herlina Dewi \\ Fakultas Hukum Universitas Warmadewa, Denpasar-Bali, Indonesia
}

\begin{abstract}
Abstrak
Ahli waris yang pindah agama dari Hindu menyebabkan ahli waris kehilangan hak warisnya. Pasalnya, dalam Hukum Adat Bali tentang waris memiliki kewajiban kepada ahli waris, keluarga, dan masyarakat adat. Hak ahli waris mutlak mendapat hak waris. Namun karena kasih sayang orang tua, banyak orang tua yang menganggap kedudukan ahli waris yang berpindah agama dengan memberikan bagian dari harta pusaka yang bukan ilmu gaib atau harta benda yang bukan merupakan warisan tetapi dikatakan sebagai hibah. Tujuan penelitian ini adalah untuk mengetahui kedudukan atau status ahli waris yang dimilikinya dikonversi dan untuk mengetahui kemungkinan apakah ahli waris dapat menerima hadiah di luar warisan. Metode penelitian yang digunakan adalah metode penelitian yuridis normatif, pendekatan yang dilakukan atas dasar bahan hukum utama dengan mengkaji teori, konsep, asas hukum dan peraturan perundang-undangan yang berkaitan dengan makalah ini. Berdasarkan isi penelitian dapat diringkas sebagai berikut: 1. Dengan perpindahan ahli waris agama, ahli waris tidak dapat melaksanakan kewajiban sebagai ahli waris ahli waris, keluarga, dan masyarakat adat. Dengan demikian hubungan waris antara ahli waris dengan ahli waris terputus sehingga akibat hukum ahli waris tidak berhak atas waris. 2. Ahli waris masih bisa menerima hadiah dari orang tuanya karena kasih sayang. Hadiah dapat berupa properti yang tidak memiliki kekuatan magis secara agama dan dapat juga diberikan dalam bentuk hibah.
\end{abstract}

Kata Kunci: Ahli Waris; Pindah Agama; Hukum Waris

\begin{abstract}
An heir changing their religion from Hindu leads them to losing their inheritance rights. This is because in Bali's Customary Law of inheritance an heir has an obligation to heirs, families, and indigenous peoples. It is absolute for the heirs to get the right of inheritance. However, because of the affection of parents, many parents consider the position of heirs who convert by giving part of the inheritance that is not magical religious or a property that is not an inheritance but is said to be a grant. The purpose of this study is to determine the position or status of an heir who has converted and to know the possibility of whether the heirs can receive a gift outside of the estate. The method of research used normative juridical research methods, approaches made on the basis of major legal material by reviewing theories, concepts, legal principles and legislation related to this paper. Based on the contents of the study can be summarized as follows: 1) with the transfer of religion heirs, heirs cannot carry out obligations as heirs to the heirs, families, and indigenous peoples. Thus the inheritance relationship between the heirs and the heirs is lost so that the legal consequences of the heir do not have the right to inherit. 2. Heirs can still accept the gift from their parents because of compassion. The gift may be a property which is not religiously magical and can also be given in the form of a grant.
\end{abstract}

Keywords: Heir; Converting Religion; Inheritance Law

\section{PENDAHULUAN}

Kebebasan beragama juga dapat menimbulkan permasalahan antara lain terjadinya peralihan agama dari satu agama ke agama lain yang diyakini, sehingga terkadang dalam suatu keluarga terjadi perbedaan agama yang dianut. Hal ini masih menjadi tanda tanya mengingat kebebasan beragama di Indonesia ini digolongkan kepada hak yang paling hakiki dan pengembangan agama secara wajar untuk agama yang diakui oleh Pemerintah. Dalam hal ni berarti pula bahwa agama Hindu yang 
walaupun pemeluknya lebih banyak di Bali, yang dalam pengembangannya selalu dimungkinkan dimana saja di seluruh Indonesia, sehingga bagi pertumbuhan ini tidak wajar apabila muncul dalihdalih apapun yang menghalangi kebebasan seseorang untuk memeluk agama yang diyakininya. Begitupula sebaliknya untuk agama-agama lain yang diakui oleh UUD 1945, adalah wajar diperlakukan sedemikian rupa. Namun penting untuk diingat di Bali sendiri terdapat konstelasi hukum tentang keagamaan. Perpindahan agama ini kemungkinan besar berpengaruh kepada sistem pembagian warisan dimana sebagian besar masyarakat di Indonesia masih menganut sistem patrilineal atau sistem pembagian warisan dari garis keturunan laki-laki (Prasetyo, 2012). Para ahli berpendapat bahwa prinsip garis keturunan yang berlaku di dalam masyarakat yang bersangkutan masih sering memepengaruhi hukum adat waris. Berpindahnya suatu agama dari agama Hindu misalnya bisa saja menimbulkan suatu permasalahan atau perbedaan pendapat dalam hal pembagian warisan.

Berhubungan dengan penelitian oleh (Wulandari, 2014) menyimpulkan bahwa dalam agama Hindu, ahli waris yang diutamakan adalah laki-laki dan memiliki kriteria tertentu dan sistem kewarisannya adalah asas patrilineal (peralihan harta waris melalui satu arah hanya dari garis lakilaki saja), sedangkan dalam Islam adalah asas bilateral (peralihan harta melalui dua arah dari garis laki-laki dan perempuan). Dalam agama Islam, ada orang tertentu yang menjadi ahli waris dengan bagian tertentu dengan sebutan ashab al- furūd, sedangkan Hindu hanya anak keturunan terutama laki-laki meski perempuan juga mendapatkan harta waris namun tidak seleluasa anak laki-laki yang mendapatkan 1 bagian ditambah $1 / 2$ apabila dia anak sulung sedangkan anak perempuan hanya mendapatkan $1 / 4$ nya saja.

Seperti yang telah diuraikan di atas, maka dapat dirumuskan permasalahan sebagai berikut: Bagaimanakah kedudukan ahli waris berpindah agama dari Hindu menurut Hukum Waris Adat Bali, dan Apakah ahli waris yang berpindah agama masih boleh menerima suatu pemberian di luar harta waris. Tujuan penelitian ini adalah untuk mengetahui kedudukan atau status ahli waris yang dimilikinya dikonversi dan untuk mengetahui kemungkinan apakah ahli waris dapat menerima hadiah di luar warisan.

\section{METODE PENELITIAN}

Metode penelitian yang digunakan ialah metode penelitian normatif. Metode penelitian normatif ini dilakukan berdasarkan bahan hukum utama, dengan cara menelaah kembali teori-teori, konsepkonsep, asas-asas hukum serta peraturan perundang-undangan yang ada hubungannya dengan penelitian ini. Teknik pengumpulan data yang dipergunakan dalam penelitian ini terdiri dari: Teknilk studi dokumen, yaitu pengumpulan data dengan mencatat bahan bahan yang ada dalam literatur maupun dokumen lainnya yang membahas tentang kedudukan ahli waris. Sedangkan pendekatan masalah yang digunakan secara yuridis yaitu dengan meninjau peraturan yang berhubungan dengan permasalahan penelitian.

\section{HASIL DAN PEMBAHASAN}

\section{Kedudukan Ahli Waris Berpindah Agama dari Hindu Menurut Hukum Waris Adat Bali}

Untuk dapat memahami mengenai kewarisan, maka perlu diperjelas dulu bagian- bagian dari pewarisan. Pewaris merupakan pokok pertama yaitu orang yang meninggalkan harta warisan (Oemar Moechthar, 2017). Kemudian, ada pula pokok yang kedua yaitu harta yang ditinggalkan oleh pewaris disebut dengan harta warisan. Kemudian, ada pokok yang ketiga yaitu penerima harta warisan yang disebut dengan ahli waris. Pengertian dari hukum adat waris menurut para ahli, yaitu :

Menurut (Hadikusuma, 2014) dikatakan bahwa : "hukum waris adat adalah hukum yang memuat ketentuan tentang system dan azas-azas hukum tentang warisan,pewariss dan cara-cara bagaimana harta warisan itu dialihkan penguasaan dan pemilikannya dari pewaris kepada ahli waris". Menurut (R.Soepomo, 1996) hukum waris adat adalah "memuat peraturan- peraturan yang mengatur proses meneruskan dang mengoperkan harta benda dan barang-barang tidak berwujud benda dari suatu angkatan manusia pada turunannya".

Secara teoritis sistem kekerabatan atau struktur sosial itu dapat dibedakan dalam 3 macam (Hadikusuma, 1990) yaitu :

1. Sistem Patrilineal, yaitu sistem keturunan mengikuti garis bapak. Di mana hanya anak lakilaki yang berhak untuk menerima warisan. 
2. Sistem Matrilineal, yaitu sistem keturunan mengikuti garis ibu. Di mana dalam system keturunan ini, anak perempuan lebih berhak untuk mewaris.

3. Sistem Parental atau bilateral, yaitu sistem keturunan mengikuti garis orang tua. Di mana anak laki-laki maupun anak perempuan berhak untuk mewaris.

Masyarakat Indonesia juga mengenal tiga macam sistem kewarisan dalam Hukum Adat (Setiady, 2009) yaitu :

1. Sistem Kewarisan Individual yaitu semua ahli waris berhak mendapatkan bagiannya untuk bisa dikuasai atau dimiliki untuk diusahakan, dinikmati ataupun dialihkan kepemilikannya.

2. Sistem kewarisan kolektif yaitu semua ahli waris diberikan harta warisan oleh pewaris namun harta warisan tersebut tidak dapat dibagi-bagi. tetapi, setiap ahli waris berhak mengusahakan, menggunakan atau mendapat hasil dari harta warisan tersebut.

3. Sistem kewarisan mayorat memiliki kesamaan dengan sistem kewarisan kolektif, yaitu harta warisan diwariskan seluruhnya atau hanya sebagian besar saja kepada satu orang anak saja.

Sistem-sistem kewarisan ini tidaklah menunjuk pada suatu bentuk susunan masyarakat tertentu atau struktur sosial tertentu dari masyarakat hukum adat di mana sistem kewarisan itu berlaku. Sebab sistem kewarisan ini dapat ditemukan juga dalam system kewarisan di masyarakat hukum adat di daerah lain. Seorang ahli waris bila ingin menuntut haknya sebagai seorang ahli waris maka haruslah menjalankan kewajiban-kewajibannya.

Pada penganut patrilineal (Rahim, 2019), syarat yang harus dipenuhi seorang ahli waris adalah :

1. Ahli waris merupakan anak kandung dari pewaris.

2. Ahli waris haruslah seorang anak laki-laki.

3. Apabila pewaris tidak memiliki anak kandung maka harta warisan dapat diberikan kepada anak yang buka sedarah atau yang disebut anak angkat.

4. Apabila pewaris tidak memiliki anak kandung maupun anak angkat, dalam

Hukum Hindu membuka kemungkinan adanya penggantian ahli waris. Menurut Hukum Adat Waris di Bali, seorang ahli waris yang berpindah agama dapat kehilangan hak untuk mewaris. Karena apabila seorang ahli waris berpindah agama dari Agama Hindu, ahli waris tidak dapat menjalankan kewajibannya terhadap pewaris, keluarga, dan juga desa adat. Keadaan yang seperti ini sering terjadi di Bali namun, tidak jarang juga di dalam masyarakat bahwa pewaris yang masih hidup memebrikan kelonggaran terhadap ahli waris dengan cara memberikan harta warisan tertentu. Orang tua yang menginginkan untuk memberikan bagian kepada anak yang beralih agama dapat memberikan harta benda pemberian yang disebut jiwa dana.

\section{Kemungkinan Ahli Waris dapat Menerima di Luar Warisan}

Seorang ahi waris yang telah berpindah agama tidak lagi memiliki hubungan dengan pewaris. Setelah ahli waris berpindah agama, ahli waris dan pewaris tidak memiliki hubungan sentana waris ataua makedeng-kedengan karena hak dan kewajiban ahli waris telah terputus. Hubungan yang tersisa antara ahli waris dengan pewaris adalah semata hubungan orang tua dan anak yang memiliki hubungan darah dengan atau secara biologis karena sebagai anak yang dilahirkan oleh orang tuanya. Sehingga kini hak dan kewajiban anak yang berpindah agama dengan orang tuanya murni hanya berdasarkan hubungan darah dan moral saja.

Dilihat dari status hukum hubungan hak dan kewajiban antara pewaris dengan ahli waris telah lepas sejak ahli waris berpindah agama. Tidak hanya hubungan hak da kewajiban dalam lingkungan keluarga tetapi juga dalam lingkungan masyarakat hukum adat di mana ahli waris tersebut tinggal. Setelah dia berpindah agama maka dia tidak lagi diikutsertakan dalam organisasi desa atau Banjar adat, tetapi jika dia masih tinggal dilingkungan desa atau Banjar yang dimaksud maka statusnya hanyalah berbanjar atau berdesa dinas saja. Dalam hal ini, seorang ahli waris yang berpindah agama tidak diperkenankan mempergunakan fasilitas adat Bali, misalnya ialah kuburan sebagai tempat bersemayam yang terakhir. Fasilitas desa yang berupa kuburan ini hanya diperuntukkan bagi masyarakat yang beragama Hindu karma desa adat tersebut. Maka ahli waris yang berpindah agama tidak diperbolehkan menguburkan mayat dikuburan desa, karena seperti yang kita ketahui bahwa tiaptiap agama sudah memiliki kuburannya masing-masing.

Kewarisan di Bali tidak boleh dilepaskan dari serentetan kewajiban keagamaan yang harus dilakukan sebagai darma bakti yang harus dilakukan kepada pewaris. Kewajiban-kewajiban yang 
harus dilakukan oleh seorang ahli waris ialah mengabenkan pewaris. Saat seorang pewaris meninggal dunia, ahli waris yang menerima haknya sebagai pewaris harus melaksanakan kewajibannya sebgaia seorang ahli waris, yaitu mengeluarkan harta sama rata sampai upacara tersebut selesai. Hal tersebut akan mudah dilaksanakan apabila ahli waris semuanya beragama Hindu. Namun, apabila ada salah satu ahli waris yang telah berpindah agama mendapatkan hak mewarisnya namun tidak ikut melaksanakan kewajibannya sebagai ahli waris hal tersebut dapat menimbulkan permasalahan dengan ahli waris yang lain.

Jika terjadi hal seperti itu, perlu diingat kembali bahwa seorang ahli waris yang berpindah agama tidak lagi memiliki hak maupun kewajiban terhadap pewaris. Namun, seorang ahli waris masih dapat menerima harta pemberian dari orang tuanya atas dasar rasa kasih dan sayang orang tua kepada anaknya dengan ketentuan orang tua memberikan harta warisan yang dapat dibagi-bagi. Pembagian warisan antara pewaris dengan ahli waris merupakan hal yang bersifat kekeluargaan, di mana seseorang yang bukan merupakan bagian dari keluarga pewaris tidak berhak untuk ikut campur.

Agar tidak terjadi permasalahan yang semakin rumit, ada baiknya saat memberikan warisan kepada ahli waris yang berpindah agama si pewaris dalam keadaan masih hidup atau pemberian warisan ini di diskusikan dulu dengan ahli-ahli waris yang lainnya.

Harta warisan yang boleh diwariskan kepada ahli waris pindah agama yaitu :

1. Harta Bawaan yaitu harta yang disebut sebagai "tetatadan" dalam Bahasa Bali, harta suami atau istri yang di bawa ke dalam suatu perkawinan, setelah lampau waktu maka harta tersebut dikatakan sebagai milik bersama.

2. Harta perkawinan adalah harta yang diperoleh suami dan istri selama masa perkawinan atau disebut dengan guna kaya.

3. Harta pusaka yang bisa dibagi-bagi ialah harta warisan yang tidak memiliki sifat magis religius. Apabila tanah yang diterima ahli waris bukan berupa warisan hal itu diperbolehkan menurut hukum adat Bali, dan dalam hukum perdata itu dikenal sebagai hibah. Maka, apabila seorang ahli waris yang berpindah ke agama lain dapat diberikan harta yang bukan merupakan warisan dari pewaris. Harta tersebut digolongkan ke dalam bentuk hibah.

\section{SIMPULAN DAN SARAN}

\section{Simpulan}

Kedudukan ahli waris yang pindah agama menurut hukum adat Bali, sebagai ahli waris diputus hak dan kewajibannya, baik yang berkaitan dengan agama, keluarga, desa adat, dan budaya masyarakat adat di Bali. Ahi waris pindah agama hanya memiliki kewajiban sebagai anak kepada orang tuanya saja, murni hanya hubungan biologis. Namun bukan berarti karena telah berpindah agama tidak lagi memenuhi kewajiban sebagai anak, dalam hal ini kewajiban sebagai anak tetap harus dijalani seperti misalnya, mengurus orang tuanya pada saat sakit atau mungkin sampai meninggal dunia. Ahli waris yang berpindah agama masih boleh menerima harta warisan dari pewaris, asalkan harta warisan tersebut merupakan harta guna kaya dari orang tuanya. Masyarakat adat Bali sendiri menyebutnya sebagai Jiwa Dana atau tetatadan, harta bawaan orang tuanya atau bisa juga harta pusaka yang dapat di bagi-bagi.

\section{Saran}

Kepada para ahli waris apabila ingin haknya sebagai ahli waris tidak hilang maka sebaiknya melaksanakan kewajiban sebagai ahli waris dengan baik dan benar serta tidak merugikan pewaris dan masyarakat di sekitar. Serta ada baiknya ahli waris tidak berpindah agama, selain agar haknya sebagai ahli waris tidak hilang juga untuk meneruskan keturunan dan untuk menjaga leluhur. Berikut hakim-hakim dalam memutus perkara mengenai ahli waris pindah agama hendaknya berlaku adil agar kedua belah pihak bisa menerima dengan kesadaran bahwa hal itulah yang terbaik, untuk menghindari perselisihan antara ahli waris satu dengan lainnya.

\section{DAFTAR PUSTAKA}

Hadikusuma, H. (1990). Hukum Waris Adat. Alumni Bandung.

Hadikusuma, H. (2014). Pengantar Ilmu Hukum Adat Indonesia. Mandar Maju Bandung.

Oemar Moechthar. (2017). Kedudukan Negara Sebagai Pengelola Warisan Atas Harta Peninggalan Tak Terurus Menurut Sistem Waris Burgerlijk Wetboek. Yuridika, 32(2), 280-309. 
Prasetyo, H. K. D. P. P. M. H. (2012). Pelaksanaan Pembagian Waris dalam Sistem Kewarisan Patrilineal Menurut Masyarakat Timika, Papua. Jurnal Notarius, 13(1).

R.Soepomo. (1996). Bab-Bab Tentang Hukum Adat. Pradnya paramita.

Rahim, A. (2019). Praktik Pembagian Waris Terhadap Ayah dan Ibu Pada Masyarakat Mandailing di Kabupaten Mandailing Natal. I(2), 25-44.

Setiady, T. (2009). Intisari Hukum Adat Indonesia dalam Kajian Pustaka. Alfabeta.

Wulandari, Y. (2014). Ketentuan Ahli Waris Menurut Agama Islam dan Hindu. 4(2). 